Article

\title{
Resource Efficiency Assessment-Comparing a Plug-In Hybrid with a Conventional Combustion Engine
}

\author{
Martin Henßler ${ }^{1}, *$, Vanessa Bach ${ }^{2}, *$, Markus Berger ${ }^{2}$, Matthias Finkbeiner ${ }^{2}$ and \\ Klaus Ruhland ${ }^{1}$ \\ Received: 22 October 2015; Accepted: 22 December 2015; Published: 21 January 2016 \\ Academic Editor: Mario Schmidt \\ 1 Group Environmental Protection, Daimler AG, Stuttgart 70546, Germany; klaus.ruhland@daimler.com \\ 2 Chair of Sustainable Engineering, Technische Universität Berlin, Straße des 17. Juni 135, Berlin 10623, \\ Germany; markus.berger@tu-berlin.de (M.B.); matthias.finkbeiner@tu-berlin.de (M.F.) \\ * Correspondence: martin.henssler@daimler.com (M.H.), vanessa.bach@tu-berlin.de (V.B.); \\ Tel.:+49-30-314-27941 (V.B.)
}

\begin{abstract}
The strong economic growth in recent years has led to an intensive use of natural resources, which causes environmental stress as well as restrictions on the availability of resources. Therefore, a more efficient use of resources is necessary as an important contribution to sustainable development. The ESSENZ method presented in this article comprehensively assesses a product's resource efficiency by going beyond existing approaches and considering the pollution of the environment as well as the physical and socio-economic availability of resources. This paper contains a short description of the ESSENZ methodology as well as a case study of the Mercedes-Benz C-Class (W 205)_comparing the conventional C 250 (petrol engine) with the C 350 e Plug-In Hybrid (electric motor and petrol engine). By applying the ESSENZ method it can be shown that the use of more and different materials for the Plug-In-Hybrid influences the dimensions physical and socio-economic availability significantly. However, for environmental impacts, especially climate change and summer smog, clear advantages of the C 350 e occur due to lower demand of fossil energy carriers. As shown within the case study, the when applying the ESSENZ method a comprehensive evaluation of the used materials and fossil energy carriers can be achieved.
\end{abstract}

Keywords: resource efficiency; life cycle assessment; physical availability; socio-economic availability; environmental impact

\section{Introduction}

The demand of abiotic resources like metals, or fossil fuels has increased significantly in recent decades due to the global industrial and technological development. Additionally, the pollution of natural resources like water has risen as well. As these patterns of resource consumption will lead to an exceedance of the sustainable capacity of ecosystems worldwide, enhancing resource efficiency is a key goal of national and international strategies (e.g., [1,2]).

There is no commonly accepted definition of the term "resources" yet. Often it is defined as materials and energy as well as knowledge, services, or staff. With regard to the assessment of efficiency of a resource the term is mostly used evaluating the use of minerals, metals, and fossil energy carriers [2-5]. The Strategy on the sustainable use of natural resources [6] includes the environment in the definition as well, leading to a more comprehensive view of resources.

Resource efficiency is mostly regarded as a macro economic strategy because resources are key components of every society to sustain production and the wellbeing of current and future 
generations [5,7]. However, often resource efficiency is implemented on a micro economic level e.g., by reducing material inputs. Thus, measuring resource efficiency in a methodologically correct yet applicable way on a product level enables companies to address scarcity of resources and decrease environmental impacts on a corporate level.

Evaluating the resource efficiency of products can be established by the ESSENZ method (Integrated method to assess/measure resource efficiency) [8-11].

In the following sections, the applied ESSENZ method is introduced as well as the subjects of the case study. Results are shown for the individual dimensions as well as for the summarized results.

\section{Method}

In cooperation with TU Berlin (Chair of Sustainable Engineering), Daimler AG, Deutsches Kupferinstitut Berufsverband e. V., Evonik Industries AG, Siemens AG, ThyssenKrupp Steel Europe AG, and Wissenschaftlicher Gerätebau Dr.-Ing. Herbert Knauer GmbH a comprehensive method has been developed to measure resource efficiency of products. Overall, 18 categories and corresponding indicators were established to enable a holistic assessment of resource efficiency in the context of sustainable development considering the three dimensions "physical availability", "socio-economic availability", and "environmental impacts" (Figure 1) [8-11]. Within the ESSENZ approach next to the environment (including all environmental compartments e.g., water, air, soil), raw materials are considered as a resource as well. Even though the developed approach can be applied to all resources in theory, practical experience has so far been limited to metals, fossil energy carriers, as well as parts of the environment.
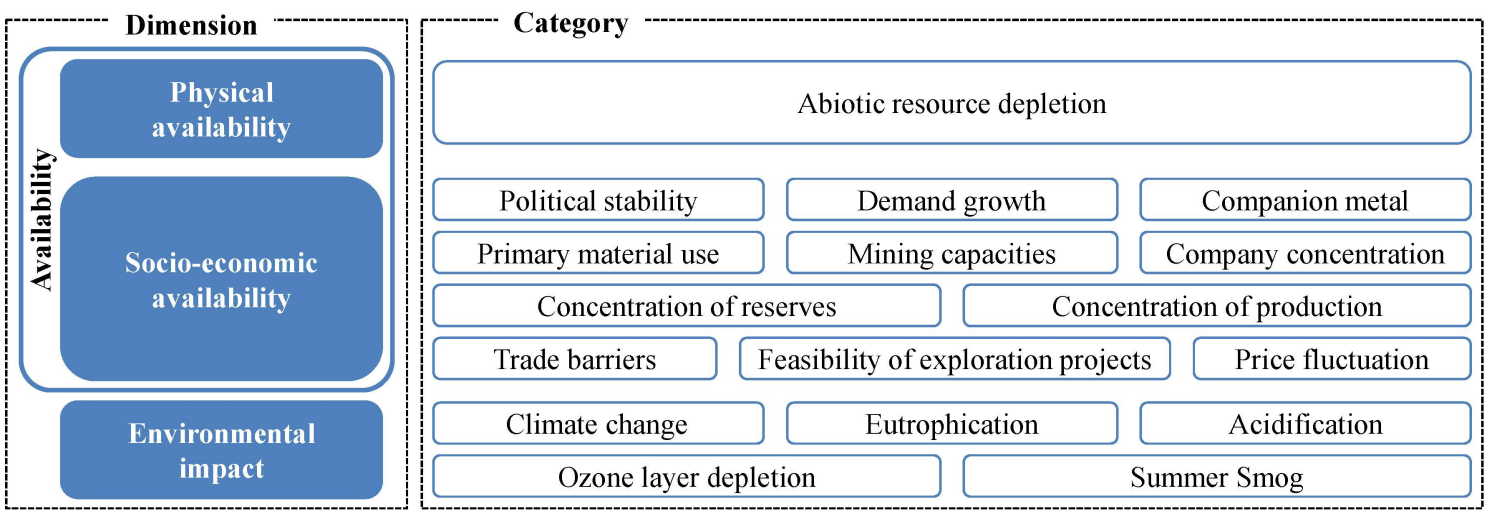

Figure 1. Dimensions and categories to assess resource efficiency within the ESSENZ method.

Existing geological deposits (physical availability) as well as socio-economic factors (socio-economic availability) might be restricting the availability of resources and thus influencing their supply security. The physical availability is evaluated by means of the abiotic depletion potential (ADP) indicator (baseline approach-ultimate reserves), which is subdivided to assess resource depletion of raw materials $\left(\mathrm{ADP}_{\text {elemental }}\right)$ and resource depletion of fossil fuels $\left(\mathrm{ADP}_{\text {fossil }}\right)$ [12]. To evaluate the socio-economic availability of resources, economic constraints leading to supply shortages along the product's value chain are quantified [13]. Possible constraints include, for example, the political stability of countries, which can be impaired due to factors such as corruption within the government, disrupting the capacity to effectively implement robust policies [14]. Based on existing work [15-17] 11 categories with corresponding category indicators are identified (Table 1). Characterization factors for all categories are determined based on the ecological scarcity approach $[18,19]$. Indicator values are compared with regard to a category specific target. These targets have been determined based on a stakeholder survey and expert interviews. Applying normalization and scaling (up to $1.5 \times 10^{19}$ representing the overall production of all considered materials within the year 2013) the calculation of the final characterization factors is concluded. They are provided for a portfolio of 36 metals and four 
fossil energy carriers [8-11]. So far, the physical and socio-economic availability of a product can only be determined for the BoM of the considered product. Due to the fact that current LCA databases use economic allocation to assign metal contents from mixed ores to metal datasets, the mass of metals in the datasets does not reflect the physically present metal content but rather represents an over- or underestimation depending on the economic value of the considered metals.

Table 1. Socio-economic categories and related category indicators.

\begin{tabular}{|c|c|c|}
\hline Category & Description & Category Indicator \\
\hline Political stability & $\begin{array}{l}\text { Governance stability of producing } \\
\text { countries }\end{array}$ & World Governance Indicators [14] \\
\hline Demand growth & $\begin{array}{l}\text { Increase of demand over the last } \\
\text { five years }\end{array}$ & $\begin{array}{l}\text { Percentage of annual growth } \\
\text { based on past developments } \\
\text { (based on data from British } \\
\text { Geological Service [20]) }\end{array}$ \\
\hline Companion metal & $\begin{array}{l}\text { Companion metals within host metal } \\
\text { ore bodies }\end{array}$ & $\begin{array}{l}\text { Percentage of production as } \\
\text { companion metal [21] }\end{array}$ \\
\hline Primary material use & Recycling content of a material & $\begin{array}{l}\text { Percentage of new material } \\
\text { content [22] }\end{array}$ \\
\hline Mining capacities & $\begin{array}{l}\text { Overall mining time of a material } \\
\text { considering current production }\end{array}$ & $\begin{array}{l}\text { Reserve-to-annual-production } \\
\text { ratio (based on data from United } \\
\text { States Geological Service [23] and } \\
\text { British Geological Service [20]) }\end{array}$ \\
\hline Company concentration & $\begin{array}{l}\text { Company concentration based on } \\
\text { producing companies }\end{array}$ & \multirow{3}{*}{$\begin{array}{l}\mathrm{HHI} \mathrm{I}^{(1)} \text { _index is calculated by } \\
\text { squaring the market share of each } \\
\text { company or country with regard } \\
\text { to the production or reserves [24] }\end{array}$} \\
\hline Concentration of reserves & $\begin{array}{l}\text { Reserve concentration of certain } \\
\text { materials based on reserves } \\
\text { in countries }\end{array}$ & \\
\hline Concentration of production & $\begin{array}{l}\text { Concentration of mine production } \\
\text { based on production in countries }\end{array}$ & \\
\hline Trade barriers & Materials underlying trade barriers & Enabling Trade Index [25] \\
\hline $\begin{array}{l}\text { Feasibility of } \\
\text { exploration projects }\end{array}$ & $\begin{array}{l}\text { Political and societal factors } \\
\text { influencing opening of mines }\end{array}$ & Policy Potential Index [26] \\
\hline Price fluctuation & Unexpected price fluctuations & Volatility [27] \\
\hline
\end{tabular}

For determining impacts of resource use on the environment five different indicators are applied using the CML-IA impact assessment method (CML 2001-Version: April 2013, baseline approach) [28] for the subjects' climate change, acidification, eutrophication, ozone layer depletion, and summer smog. The considered environmental impact categories as well as methods are chosen based on their applicability and maturity [29]. Thus, biodiversity and land use are not included as no adequate and applicable methods exist so far [30].

For an overall result regarding the resource efficiency of a product system the considered categories are analyzed together to achieve a comprehensive evaluation enabling meaningful decision making [8-11].

\section{Case Study of Mercedes-Benz C-Class}

In the following section, the resource efficiency assessment according to the ESSENZ method is presented for the example of the C-Class (W 205). The study compares the conventional C 250 (petrol engine) with the C 350 e Plug-In Hybrid (electric motor and petrol engine). First, in Section 3.1 
technical data and a detailed analysis of materials for the considered passenger cars are provided. Results of the resource efficiency assessment with the ESSENZ method are shown in Section 3.2.

\subsection{Product Documentation of the $C 250$ and $C 350 e$}

This section documents significant specifications of the different variants of the C-Class analyzed in this study. Section 3.1.1. provides an overview of the technical data of the C 250 and C 350 e. The material composition is discussed in Section 3.1.2.

\subsubsection{Technical Data}

The Plug-In Hybrid model in the current C-Class, the C 350 e, combines a $60 \mathrm{~kW}$ electric motor and an externally rechargeable battery with a four-cylinder petrol engine with $155 \mathrm{~kW}$ (Table 2). The high voltage lithium-ion battery of the C 350 e has an energy content of $6.38 \mathrm{kWh}$. With the aid of the synchronous electric motor, the $C 350$ e has an all-electric range of $31 \mathrm{~km}$. The certified combined consumption according to the New European Driving Circle (NEDC) of the C 350 e is 2.11 and $11.0 \mathrm{kWh}$ per 100 kilometer (ECE-R101). This corresponds to $\mathrm{CO}_{2}$-emissions of $48 \mathrm{~g} / \mathrm{km}$.

Table 2. Technical data of C 250 and C 350 e [31].

\begin{tabular}{ccc}
\hline Technical Data & C 250 & C 350 e \\
\hline Weight $(\mathrm{kg})$ & $1435^{1}$ & 1705 \\
Output $(\mathrm{kW})^{2} \mathrm{combined}(\mathrm{l} / 100 \mathrm{~km})$ & 155 & $155+60$ (electric motor) \\
Fuel consumption NEDC ${ }^{2}$ combined $(\mathrm{kWh} / 100 \mathrm{~km})$ & - & 2.1 \\
Electric energy consumption NEDC & 11.0 \\
Electric range $(\mathrm{km})$ & 100 & 31 \\
Driving share petrol engine $(\%)$ & - & $45^{3}$ \\
Driving share electric motor $(\%)$ & 123 & $55^{3}$ \\
$\mathrm{CO}_{2}(\mathrm{~g} / \mathrm{km})$ & 48 \\
\hline
\end{tabular}

Notes: ${ }^{1}$ Comparably equipped as C 350 e; ${ }^{2}$ NEDC: New European Driving Circle; ${ }^{3}$ Determination of electric driving share according to type approval directive ECE-R101; percentages related to driving distance.

The C 250 is powered by the $155 \mathrm{~kW}$ four-cylinder petrol engine (Table 2). The fuel consumption is $5.31 / 100 \mathrm{~km}$ (NEDC). This causes $\mathrm{CO}_{2}$-emissions of $123 \mathrm{~g} / \mathrm{km}$ which are more than twice as high as the $\mathrm{CO}_{2}$-emissions of the $\mathrm{C} 350 \mathrm{e}$.

The C 250 and the C 350 e can be assumed to be functionally equivalent as they have similar driving performance as well as safety and comfort features (Table 2). The use phase is calculated on the basis of a mileage of $200,000 \mathrm{~km}$. The key components of both vehicles (incl. battery) do not require replacement over the life cycle.

\subsubsection{Material Composition}

The weight and material data for the $C 250$ and C 350 e are determined on the basis of internal documentation of the components used in the vehicle (parts list, drawings). The kerb weight according to DIN 70020 (without driver and luggage, fuel tank 90 percent full) serves as a basis for the life cycle assessment (LCA). Figure 2 shows the material composition of the $C 250$ and C 350 e.

The weight of the $C 250$ is $1435 \mathrm{~kg}$. The weight of the $C 350 \mathrm{e}$ is $1705 \mathrm{~kg}$ and thus $270 \mathrm{~kg}$ heavier than the C 250. Steel/ferrous materials account for slightly less than half the vehicle weight (approximately 47 percent) in both cars. The next largest shares are light alloys at 21 percent and polymer materials at 19 (C 250) and 21 percent (C 350 e). Service fluids and other metals comprise around 5 (C 350 e) and 6 percent (C 250); and 2 (C 250) and 5 percent (C 350 e), respectively. The proportions of other materials are somewhat lower, at about 4 percent. 


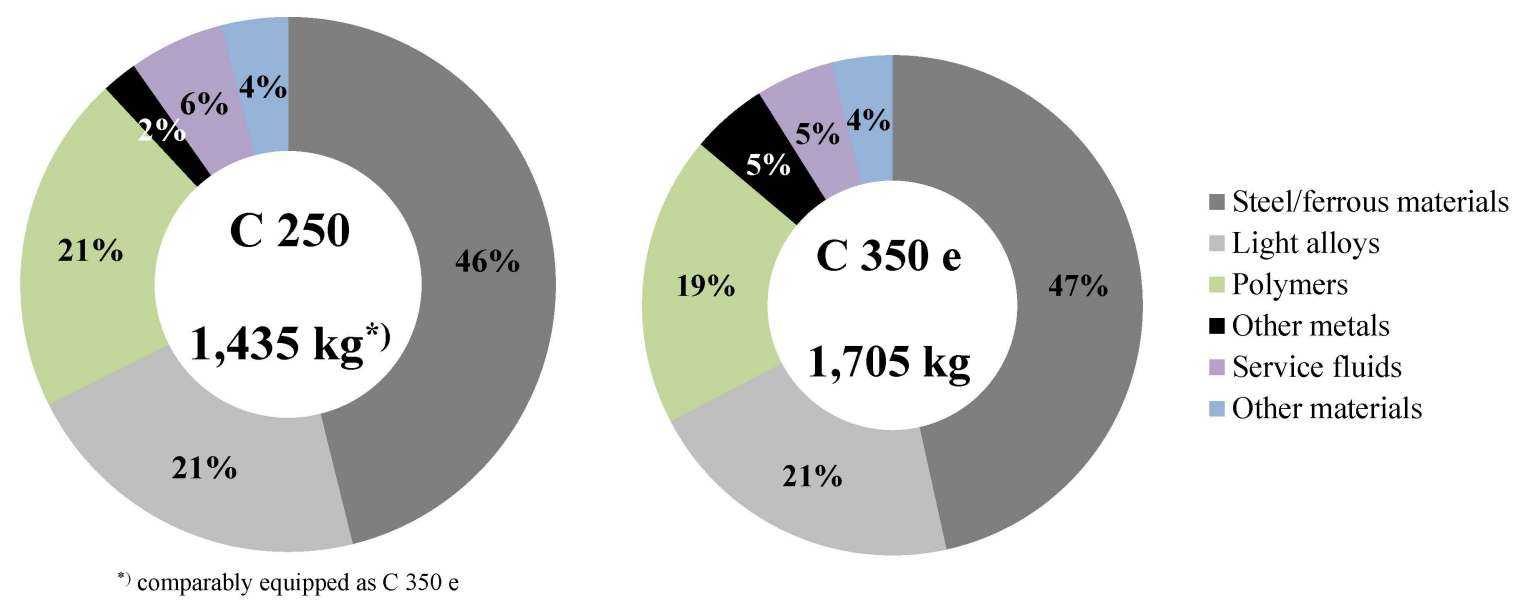

Figure 2. Material composition of C 250 and C 350 e [31].

Figure 3 shows the main differences in weight and material mix in the modules exterior, interior, chassis, powertrain, and electric comparing the $C 350$ e with the $C 250$. The biggest difference can be found regarding electric constituents. Due to the hybrid components, especially the high voltage battery, the power electronics, and the cabling, the additional weight is about $140 \mathrm{~kg}$. In the powertrain, an extra weight of about $76 \mathrm{~kg}$ is derived primarily from the electric motor. Larger breaks and tires as well as air suspension cause an extra weight of the chassis of about $66 \mathrm{~kg}$. The weight of the exterior is about $25 \mathrm{~kg}$ higher due to the high voltage crash package of the battery. The alternative drive components and the related mix of materials - especially the material group of other metals-used in the $\mathrm{C} 350$ e change the weight substantially compared to the conventional C-Class.

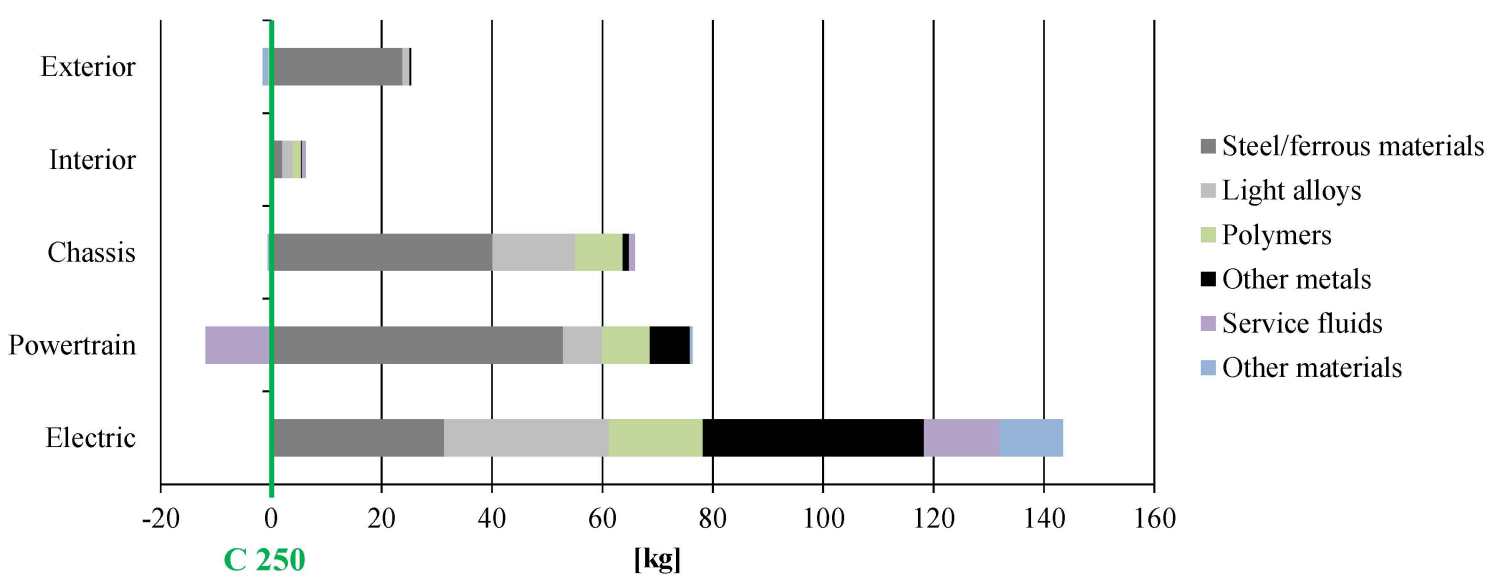

Figure 3. Main weight differences-C 350 e compared to the C 250.

\subsection{Assessment of Different Resource Efficiency Dimensions Considered in the ESSENZ Method}

The ESSENZ method described in Section 2 was applied, leading to the following results regarding physical availability (Section 3.2.1.), socio-economic availability (Section 3.2.2.), and environmental impacts (Section 3.2.3.). The section concludes by summarizing the results of all considered dimensions of the $C 250$ compared to the $C 350$ e (Section 3.2.4.).

For the $\mathrm{C} 350 \mathrm{e}$, two energy consumption scenarios for the use phase are considered. In addition to the EU electricity grid mix, electricity from hydro power is accounted for. The results of the use phase (electricity generation, fuel production, and operation) are based on the certified NEDC electricity / fuel consumption and the certified specific emissions of each car via a mileage of $200,000 \mathrm{~km}$. The study includes environmental impacts of the recovery phase on the basis of the standard processes 
of drainage, shredding, and recovery of energy from the shredder light fraction. Environmental credits are not considered.

\subsubsection{Physical Availability}

Figure 4 shows the results for the category abiotic resource depletion (quantified by $\mathrm{ADP}_{\text {elemental }}$ in $\mathrm{kg} \mathrm{Sb}$ eq and $\mathrm{ADP}_{\text {fossil }}$ in GJ). For the calculation of the $\mathrm{ADP}_{\text {elemental }}$ only the BoM of the vehicle is taken into account since no consistent background data for the whole supply chain are available andno materials are required in the use phase. Assessing resource depletion of fossil energy carriers $\left(\mathrm{ADP}_{\text {fossil }}\right)$ the whole life cycle (car production, fuel production, operation, electricity generation, and end of life) of the vehicle is included. The additional hybrid-specific components (Section 3.1.2.) lead to a higher resource depletion potential of metals for the $C 350 \mathrm{e}$, which is about 170 percent higher $(0.63 \mathrm{~kg} \mathrm{Sb}$ eq $)$ compared to the $\mathrm{C} 250(0.23 \mathrm{~kg} \mathrm{Sb}$ eq $)$.

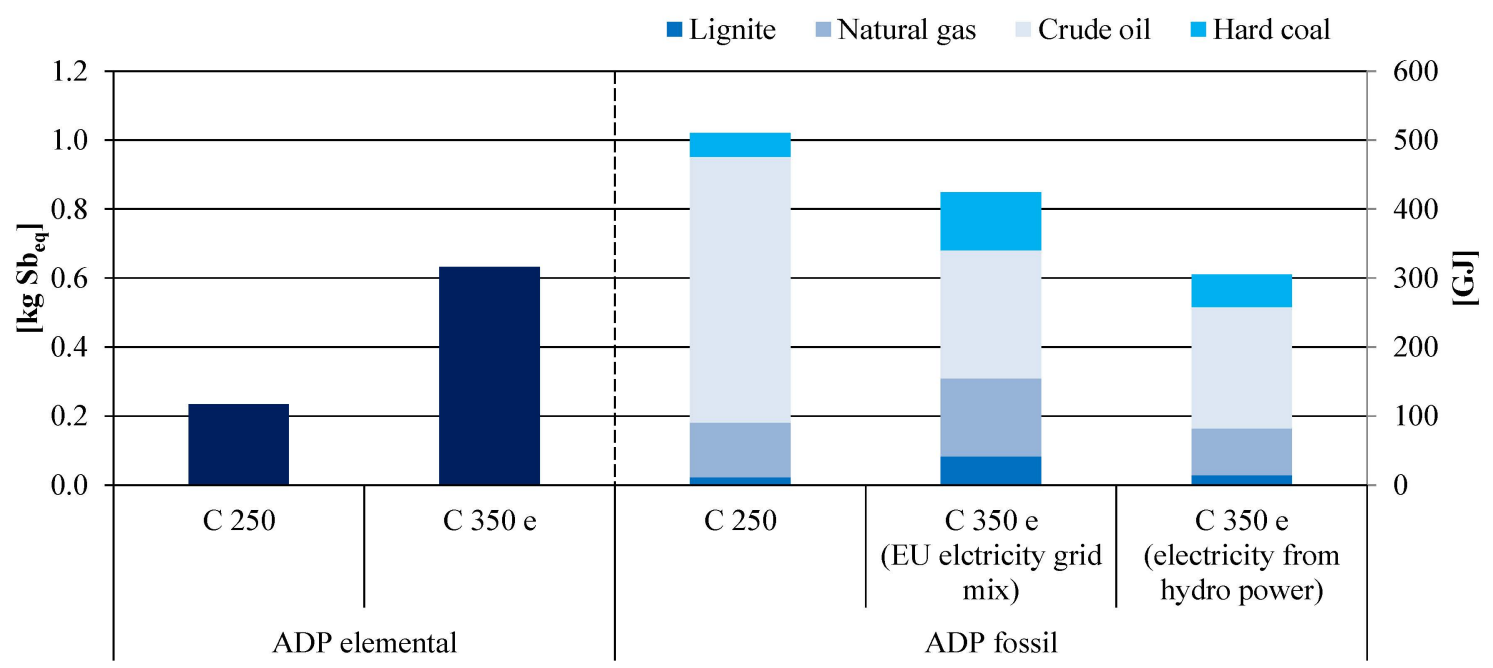

Figure 4. $\mathrm{ADP}_{\text {elemental }}$ and $\mathrm{ADP}_{\text {fossil }}-\mathrm{C} 250$ compared to the $\mathrm{C} 350 \mathrm{e}$.

The abiotic depletion potential $\left(\mathrm{ADP}_{\text {fossil }}\right)$ of the $\mathrm{C} 350$ e with electricity from hydro power is 40 percent lower $(205.6 \mathrm{GJ})$ than of the C 250 ( $511 \mathrm{GJ}$ —comprised of $385.6 \mathrm{GJ}$ crude oil, $78.8 \mathrm{GJ}$ natural gas, 34.6 GJ hard coal, and 12.7 GJ lignite). Due to additional hybrid-specific components in the car production and the generation of electricity during the operation phase, the consumption of natural gas, hard coal, and lignite rises for the C 350 e using EU electricity grid mix to $112.9 \mathrm{GJ}$ (natural gas), 84.1 GJ (hard coal), and $41.8 \mathrm{GJ}$ (lignite). Crude oil consumption can be reduced by over 50 percent to $185.6 \mathrm{GJ}$ due to the high efficiency of the Plug-In Hybrid. When the vehicle is charged with renewably generated electricity, the consumption of lignite, natural gas, crude oil, and hard coal can be reduced further.

Evaluating the abiotic resource depletion enables a comprehensive assessment of the physical availability of metals and fossil energy carriers. Advantages in the production of conventional vehicle concepts compared to alternative vehicle concepts due to the reduced consumption of materials could be shown. Furthermore, alternative engines show benefits in the use phase (electricity generation, fuel production, and operation) due to lower fuel consumption.

\subsubsection{Socio-Economic Availability}

The dimension "socio-economic availability" is quantified by 11 categories (Section 2). Regarding the socio-economic availability of metals the BoMs of the respective cars are taken into account. As most fossil energy carriers are consumed in the use phase, the whole life cycle is considered when analyzing their socio-economic availability. The results of the comparison of $C 250$ and C 350 e are shown in Figure 5 (C 250 is scaled to 100 percent). 
Overall, for the calculation of the socio-economic availability, 33 metals (Section 2) are taken into account in addition to the fossil energy carriers' lignite, natural gas, crude oil, and hard coal. As shown in Figure 5, the fossil energy carriers have little influence on the 11 categories. Exceptions are "Primary material use" (19 to 39 percent), "Price fluctuation" (12 to 28 percent), and "Company concentration" ( 2 to 5 percent). Due to the higher material consumption of the $C 350$ e the $C 250$ performs far better in all categories except for "Mining capacities". The source of electricity used to charge the C $350 \mathrm{e}$ has no impact regarding the socio-economic availability. The C 350 e using EU electricity grid mix is almost on par with C 350 e using electricity from hydro power-except differences in the categories "Primary material use" and "Price fluctuation" due to higher amounts of used fossil energy carriers (see Section 3.2.1.).

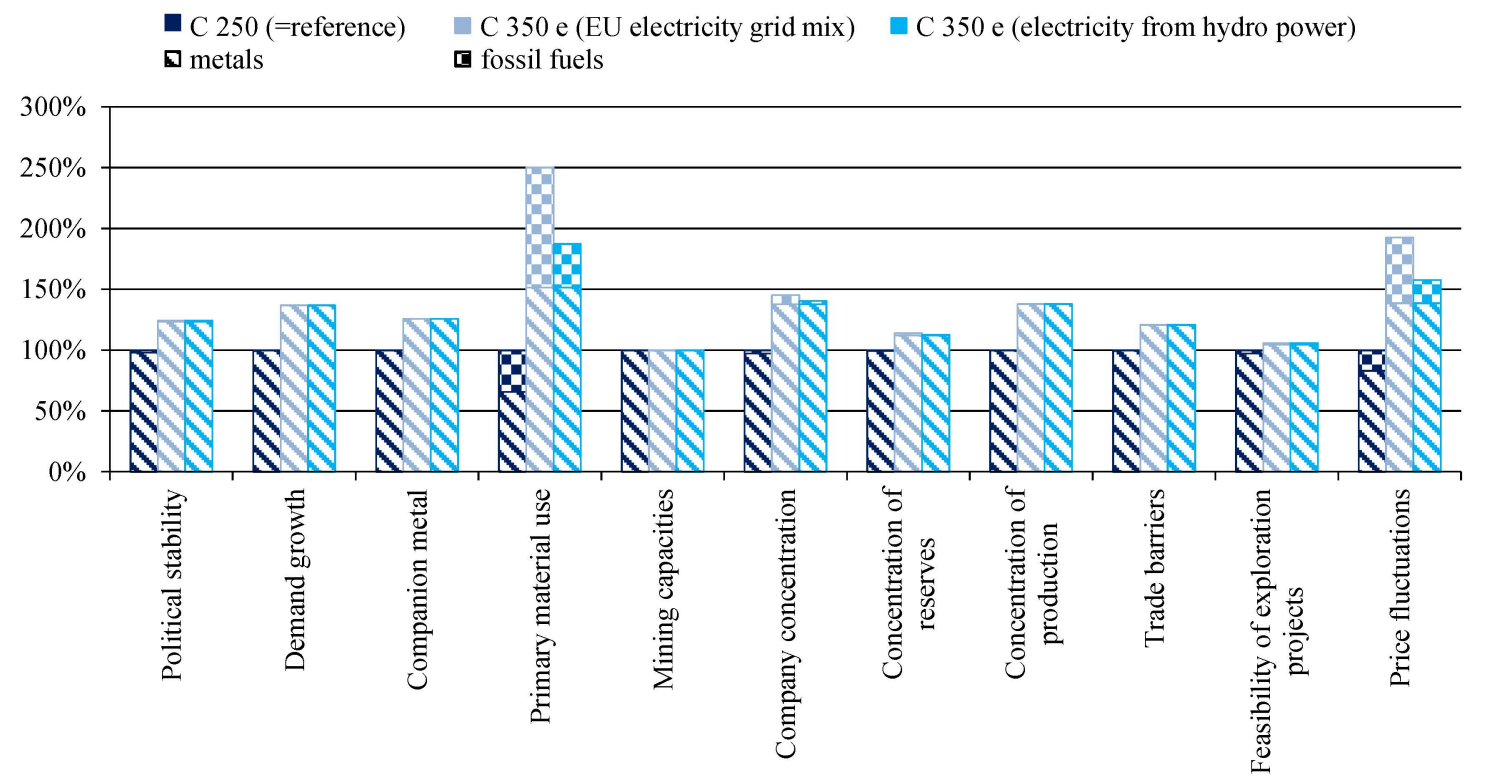

Figure 5. Assessment of the socio-economic availability-C 250 compared to the $C 350$ e.

The greatest differences between the C 250 and the C 350 e (EU electricity grid mix) occur in the categories "Primary material use" (+ 150 percent), "Price fluctuation" (+ 93 percent), "Company concentration" (+ 45 percent), "Concentration of production" (38 percent), and "Demand growth" (+ 37 percent). Regarding the categories "Demand growth" and "Primary material use", the differences are caused by the use of lithium, which is an essential part of the high voltage battery of the Plug-In Hybrid. The categories "Company concentration", "Concentration of production", and "Price fluctuation" are primarily affected by rare earth elements, which are mainly required for the magnets of the electric motor.

For the categories "Political stability", "Companion metal", "Mining capacities", "Concentration of reserves", "Trade barriers", and "Feasibility of exploration projects" the C 350 e performs up to 26 percent worse than the $C 250$. These categories are mainly affected by platinum and palladium (exhaust catalyst), magnesium (alloy material), lithium (high voltage battery), rare earth elements (electric motor), and tantalum (condensers).

Overall, it can be concluded that the socio-economic categories in this case study are particularly affected by platinum, palladium, magnesium, lithium, rare earth and tantalum. Except for magnesium, all materials occur in the car in very small amounts.

\subsubsection{Environmental Impacts}

Figure 6 shows the results of the considered environmental categories climate change ( $\mathrm{CO}_{2 \mathrm{eq}}$-emissions), eutrophication (phosphate $\mathrm{eq}^{-e m i s s i o n s), ~ a c i d i f i c a t i o n ~}\left(\mathrm{SO}_{2 \mathrm{eq}}\right.$-emissions), and 


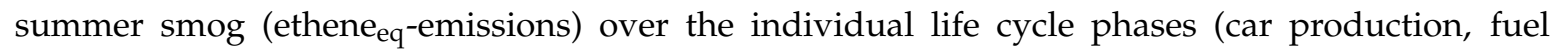
production, operation, electricity generation, and end of life) of the $\mathrm{C} 250$ and $\mathrm{C} 350 \mathrm{e}$.

The production of the $\mathrm{C} 350$ e entails visibly higher $\mathrm{CO}_{2 \mathrm{eq}}$-emissions on account of the additional hybrid-specific components. The $\mathrm{CO}_{2 \text { eq }}$-emissions in the production phase $\left(11.3 \mathrm{tCO}_{2 \mathrm{eq}}\right)$ are 32 percent higher than those of the $\mathrm{C} 250\left(8.6 \mathrm{tCO}_{2 \mathrm{eq}}\right)$. Over the entire life cycle the Plug-In Hybrid has clear advantages as external charging with the EU electricity grid mix can cut overall $\mathrm{CO}_{2 \text { eq }}$-emissions by about 13 percent $\left(4.9 \mathrm{t} \mathrm{CO}_{2 \text { eq }}\right)$ compared to the $\mathrm{C} 250$. A reduction of 39 percent $\left(15.3 \mathrm{t} \mathrm{CO}_{2 \mathrm{eq}}\right)$ is possible through the use of renewably generated electricity from hydro power.

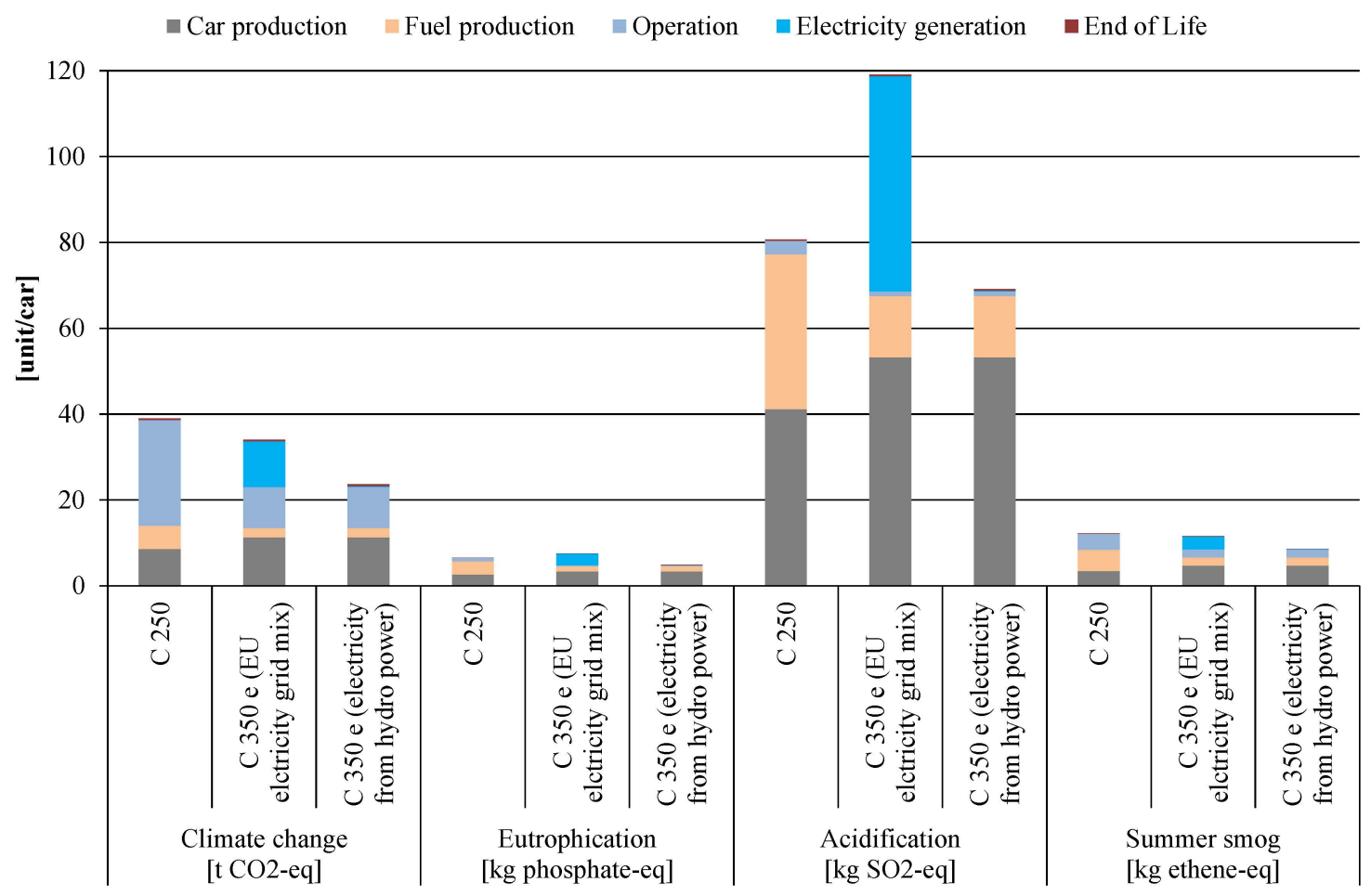

Figure 6. Selected environmental categories-C 250 compared to the C 350 e (unit/car) [24].

Considering the category eutrophication, the $\mathrm{C} 350$ e using electricity from hydro power causes

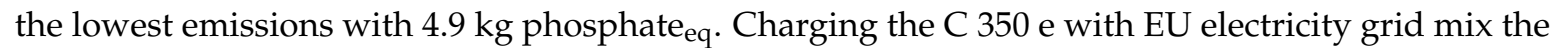

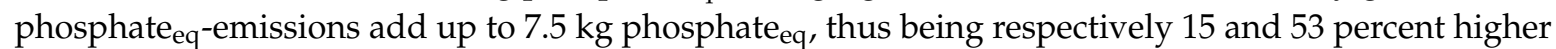

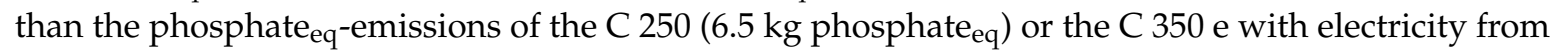
hydro power.

In the production phase of the $\mathrm{C} 350$ e $\left(53.2 \mathrm{~kg} \mathrm{SO}_{2 \mathrm{eq}}\right)$ the $\mathrm{SO}_{2 \mathrm{eq}}$-emissions are 29 percent higher than those of the $\mathrm{C} 250$ (41.2 $\mathrm{kg} \mathrm{SO}_{2 \mathrm{eq}}$ ). In the use phase (electricity generation, fuel production, and operation) most $\mathrm{SO}_{2 \mathrm{eq}}$-emissions $\left(65.5 \mathrm{~kg} \mathrm{SO} \mathrm{S}_{2 \mathrm{eq}}\right.$ ) are produced during the charging of the vehicle with EU electricity grid mix. Thus, 40 and 76 percent more emissions occur than for the $C 250$ or the $C 350 \mathrm{e}$ with electricity from hydro power respectivly. Over the entire life cycle, the $\mathrm{C} 350 \mathrm{e}$ with electricity from hydro power saves 42 percent $(50.0 \mathrm{~kg} \mathrm{SO}$ eq $)$ in comparison to the $\mathrm{C} 350$ e with EU electricity grid mix and 14 percent (11.6 $\mathrm{kg} \mathrm{SO}_{2 \mathrm{eq}}$ ) compared to the $\mathrm{C} 250$.

The summer smog emissions during production of the $C 350$ e $\left(4.7 \mathrm{~kg}\right.$ ethene $\mathrm{eq}_{\text {) }}$ are 36 percent higher than those of the $C 250$ ( $3.4 \mathrm{~kg}$ ethene $\mathrm{eq}$ ). Regarding the use phase (electricity generation, fuel production and operation) summer smog emissions can be reduced by 22 percent charging the $C 350 \mathrm{e}$ with EU electricity grid mix respectively by 55 percent using electricity from hydro power compared to the $C 250$. The highest summer smog emissions with $12.1 \mathrm{~kg}$ ethene $e_{\text {eq }}$ are caused by the $C 250$. 
Compared to the $\mathrm{C} 350$ e charged with EU electricity grid mix as well as renewable generated electricity summer smog can be reduced by 5 or 29 percent, translating in a reduction of 11.5 or $8.6 \mathrm{~kg}$ ethene $\mathrm{eq}_{\text {. }}$

In conclusion, it can be stated that over the entire life cycle the $\mathrm{C} 350$ e using electricity from hydro power has clear benefits in all considered categories (shown in Figure 6) compared to the $C 250$. If the EU electricity grid mix is used for charging advantages with respect to climate change and summer smog occur. However, with regard to eutrophication and acidification, the $\mathrm{C} 350$ e respectively has 15 percent $\left(1.0 \mathrm{~kg}\right.$ ethene $e_{\mathrm{eq}}$ ) and 48 percent $\left(38.4 \mathrm{~kg} \mathrm{SO} \mathrm{S}_{2 \mathrm{eq}}\right)$ more impacts than the $\mathrm{C} 250$.

\subsubsection{Summary of the Results}

Figure 7 shows the summary of the three dimensions considered in this case study. The reference C 250 is scaled to 100 percent.

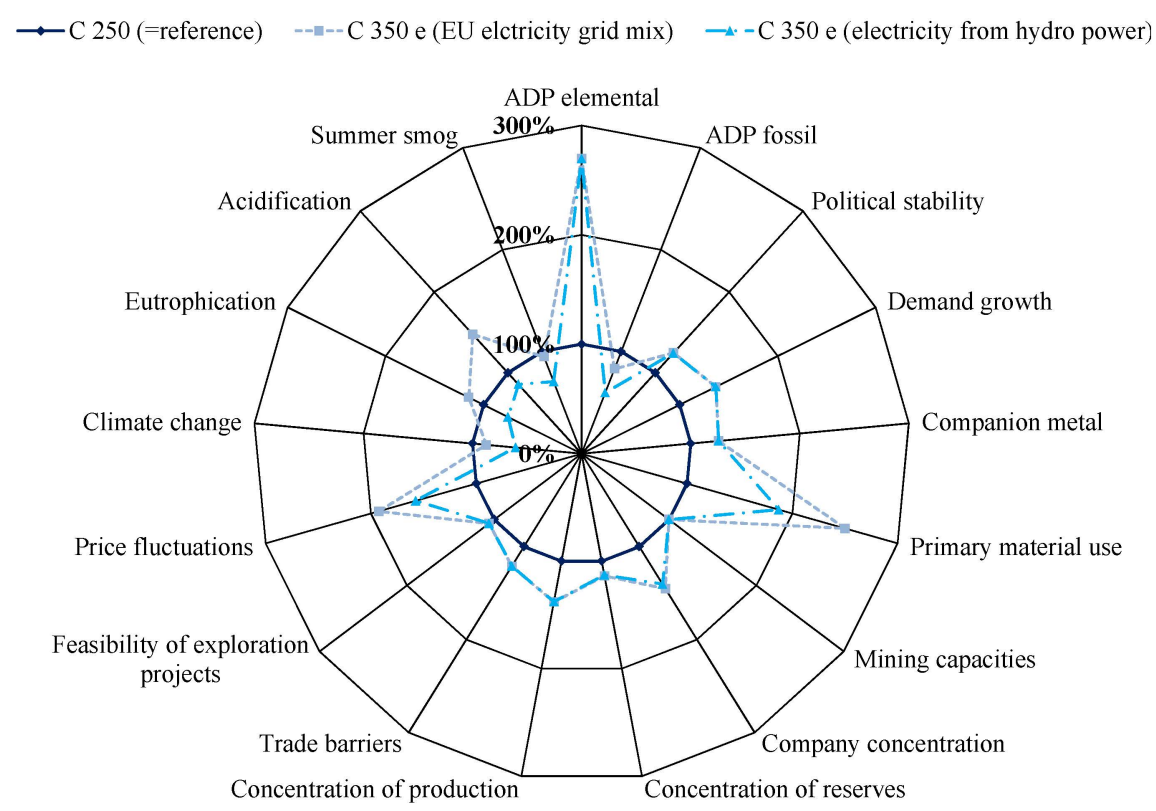

Figure 7. Summary of resource efficiency dimensions of the ESSENZ method-C 250 compared to the C 350 e.

It can be seen that the $C 250$ performs better within the category abiotic resource depletion of metals $\left(\mathrm{ADP}_{\text {elemental }}\right)$ compared to the $\mathrm{C} 350$ e due to its lower overall use of metals. This is also reflected in the dimension "socio economic availability". As the $C 250$ has a higher fossil energy carrier consumption in the use phase, it performs worse in the category resource depletion of fossil energy carriers $\left(\mathrm{ADP}_{\text {fossil }}\right)$. Both $\mathrm{C} 350 \mathrm{e}$ 's have advantages in the use phase (electricity generation, fuel production and operation) due to their lower fuel consumption.

Only minor differences for the dimension "socio-economic availability" as well as the category resource depletion of raw materials $\left(\mathrm{ADP}_{\text {elemental }}\right)$ occur when comparing the $\mathrm{C} 350$ e charged with electricity from hydro power with the $\mathrm{C} 350$ e charged with EU electricity grid mix. The metals used for car production influence the categories more significantly than the energy consumption in the use phase. For the category resource depletion of fossil energy carriers $\left(\mathrm{ADP}_{\text {fossil }}\right)$ the $\mathrm{C} 350$ e (electricity from hydro power) performs only slightly better.

The results of the environmental impacts measured over the entire life cycle show clear advantages for the C 350 e especially for the categories climate change and summer smog, regardless of the kind of electricity used for external charging of the Plug-In Hybrid. The results for the categories eutrophication and acidification, however, depend on the electricity used for charging the vehicle. Using EU electricity 
grid mix eutrophying or acidifying emissions of C 350 e are higher than those of C 250. Using electricity from hydro power, the eutrophication potential or acidification potential are lower compared to $C 250$.

\section{Conclusions}

The ESSENZ method allows a transparent evaluation of product systems with regard to the physical and socio-economic availability of fossil energy carriers and metals as well as related environmental impacts over the life cycle.

The case study presented in this article-comparing a plug-in hybrid with a conventional engine-is a good example of why such a comprehensive assessment is necessary. The higher use of material resources for the Plug-In Hybrid vehicle has a strong influence on socio-economic and physical availability, whereas some of the environmental impact categories (e.g., climate change and summer smog) show clear advantages for the C 350 e due to the lower demand of fossil energy carriers. As a consequence, it is necessary for a scientifically robust and sustainability oriented resource assessment to consider both materials and energy resources as well as the whole lifecycle of the product.

The comprehensive ESSENZ method enables the user to transparently evaluate various views on the multitude of parameters applicable. It further empowers companies to take appropriate actions regarding the specific materials used in their products, e.g., material specific sourcing strategies or development of recycling technologies.

Acknowledgments: The paper is based on the project "ESSENZ_-Integrierte Methode zur ganzheitlichen Berechnung/Messung von Ressourceneffizienz" which was funded by the German Federal Ministry of Education and Research (BMBF) - project code number: 033R094A. We would like to thank the Federal Ministry of Education and Research for their financial support.

Author Contributions: Martin Henßler was the lead in carrying out the case study. Vanessa Bach was leading in the development of the ESSENZ method. Markus Berger and Matthias Finkbeiner both provided substantial contributions to the design of the ESSENZ method as well as valuable comments to deepen the conclusion. Klaus Ruhland gave substantial input to the design of the case study as well as valuable comments to draw the conclusion. All authors proofread and approved the final manuscript.

Conflicts of Interest: The authors declare no conflict of interest.

\section{References}

1. European Commission. Roadmap to a Resource Efficient Europe; European Commission: Brüssel, Belgium, 2011.

2. Bundesregierung Deutschland. Nationale Nachhaltigkeitsstrategie Fortschrittsbericht 2012. Available online: http:/ / www.bundesregierung.de/Webs/Breg/DE/Themen/Nachhaltigkeitsstrategie/1-die-nationale-na chhaltigkeitsstrategie/nachhaltigkeitsstrategie/_node.html;jsessionid=AB7764D74BA79942AF3B8D3300348 11D.s3t2 (accessed on 18 January 2016).

3. Ritthoff, M.; Rohn, H.; Liedtke, C. Calculating MIPS-Resource Productivity of Products and Services; Environment and Energy Report; Wuppertal Institute for Climate: Wuppertal, Germany, 2002. Available online: http:/ / epub.wupperinst.org/files/1577/WS27e.pdf (accessed on 18 January 2016).

4. European Commission. Resource Efficiency. The Roadmap's Approach to Resource Efficiency Indicators. Available online: http://ec.europa.eu/environment/resource_efficiency/targets_indicators/roadmap/ index_en.htm (accessed on 18 December 2015).

5. Schneider, L.; Bach, V.; Finkbeiner, M. LCA Perspectives for Resource Efficiency Assessment. In Special Types of LCA; Springer: Berlin, Germany, 2015.

6. Thematic Strategy on the Sustainable Use of Natural Resources. Available online: http://eur-lex.europa.eu/ legal-content/EN/TXT/?uri=celex\%3A52005DC0670 (accessed on 18 January 2016).

7. Mikesell, R.F. Viewpoint-Sustainable development and mineral resources. Resour. Policy 1994, 20, 83-86. [CrossRef]

8. Bach, V.; Berger, M.; Henßler, M.; Kirchner, M.; Leiser, S.; Mohr, L.; Rother, E.; Ruhland, K.; Schneider, L.; Tikana, L.; et al. Integrierte Methode zur Ganzheitlichen Berechnung/Messung von Ressourceneffizienz (ESSENZ-Methode); Springer, 2016; in press. 
9. Bach, V.; Schneider, L.; Berger, M.; Finkbeiner, M. ESSENZ-Projekt: Entwicklung einer Methode zur Bewertung von Ressourceneffizienz auf Produktebene. In 3. Symposium Rohstoffeffizienz und Rohstoffinnovation; Fraunhofer Verlag: Stuttgart, Germany, 2014; pp. 463-474.

10. Bach, V.; Schneider, L.; Berger, M.; Finkbeiner, M. Methoden und Indikatoren zur Messung von Ressourceneffizienz im Kontext der Nachhaltigkeit. In Recycling und Rohstoffe; Thome-Kozmiensky, K.J., Goldmann, D., Eds.; TK Verlag: Neuruppin, Germany, 2014; pp. 87-101.

11. Bach, V.; Berger, M.; Helbig, T.; Finkbeiner, M. Measuring a product's resource efficiency-A case study of smartphones. In Proceedings of the CILCA 2015-VI International Conference on Life Cycle Assessment, Lima, Peru, 13-16 March 2015.

12. Van Oers, L.; de Koning, A.; Guinée, J.B.; Huppes, G. Abiotic Ressource Depletion in LCA Improving Characterisation Factors for Abiotic Resource Depletion as Recommended in the Dutch LCA Handbook, 2002. Available online: http://www.leidenuniv.nl/cml/ssp/projects/lca2/report_abiotic_depletion_web.pdf (accessed on 24 December 2015).

13. Schneider, L.; Berger, M.; Schüler-Hainsch, E.; Knöfel, S.; Ruhland, K.; Mosig, J.; Bach, V.; Finkbeiner, M. The economic resource scarcity potential (ESP) for evaluating resource use based on life cycle assessment. Int. J. Life Cycle Assess. 2014, 19, 601-610. [CrossRef]

14. The World Bank Group. The Worldwide Governance Indicators. Available online: http://info.worldbank.org/ governance/wgi/index.aspx\#home (accessed on 18 December 2015).

15. Graedel, T.E.; Barr, R.; Chandler, C.; Chase, T.; Choi, J.; Christoffersen, L.; Friedlander, E.; Henly, C.; Jun, C.; Nassar, N.T.; et al. Methodology of metal criticality determination. Environ. Sci. Technol. 2012, 46, 1063-1070. [CrossRef] [PubMed]

16. Schneider, L. A Comprehensive Approach to Model Abiotic Resource Provision Capability in the Context of Sustainable Development. Ph.D. Thesis, Technische Universität Berlin, Berlin, Germany, 6 August 2014.

17. Erdmann, L.; Behrendt, S.; Feil, M. Kritische Rohstoffe für Deutschland "Identifikation aus Sicht Deutscher Unternehmen Wirtschaftlich Bedeutsamer Mineralischer Rohstoffe, Deren Versorgungslage Sich Mittel-Bis Langfristig als Kritisch Erweisen Könnte", 2011. Available online: https://www.kfw.de/ Download-Center/Konzernthemen/Research/PDF-Dokumente-Sonderpublikationen/Kritische-RohstoffeKF.pdf (accessed on 24 December 2015).

18. Frischknecht, R.; Steiner, R.; Jungbluth, N. The Ecological Scarcity Method-Eco-Factors 2006; Federal Office for the Environment FOEN: Bern, Switzerland, 2009.

19. Müller-Wenk, R.; Ahbe, S.; Braunschweig, A.; Müller-Wenk, R. Methodik für Ökobilanzen auf der Basis ökologischer Optimierung; Schriftenreihe Umwelt 133; Bundesamt für Umwelt BAFU (former BUWAL): Bern, Switzerland, 1990.

20. Brown, J.; Wrighto, C.E.; Raycraft, E.R.; Shaw, R.A.; Deady, E.A.; Rippingale, J.; Bide, T.; Idoine, N. World Mineral Production; British Geological Survey: Keyworth, UK, 2014.

21. Angerer, G.; Erdmann, L.; Marscheider-Weidemann, F.; Scharp, M.; Lüllmann, A.; Handke, V.; Marwerde, M. Rohstoffe für Zukunftstechnologien Rohstoffe für Zukunftstechnologien; Fraunhofer IRB Verlag: Stuttgart, Germany, 2009. Available online: http://www.isi.fraunhofer.de/isi-wAssets/docs/n/de/publikationen/ Schlussbericht_lang_20090515_final.pdf (accessed on 18 January 2016).

22. Graedel, T.E. UNEP Recycling Rates of Metals-A Status Report; Working Group on the Global Metal Flows; International Resource Panel, United Nations Environment Programme: Nairobi, Kenya, 2011. Available online: http://www.unep.org/resourcepanel-old/portals/24102/pdfs/UNEP _report2_Recycling_130920.pdf (accessed on 24 December 2015).

23. United States. Geological. Service (USGS). Commodity Statistics and Information, 2015. Available online: http://minerals.usgs.gov/minerals/pubs/commodity/ (accessed on 20 May 2004).

24. Rhoades, S.A. The Herfindahl-Hirschman index. Fed. Reserv. Bull. 1993, 79, 188.

25. Hanouz, M.D.; Geiger, T.; Doherty, S. The Global Enabling Trade Report 2014; World Economic Forum: Geneva, Switzerland, 2014.

26. Cervantes, M.; McMahon, F.; Wilson, A. Survey of Mining Companies: 2012/2013; Fraser Institut: Vancouver, BC, Canada, 2013.

27. Bundesanstalt für Geowissenschaften und Rohstoffe. In Volatilitätsmonitor; Bundesanstalt für Geowissenschaften und Rohstoffe: Hanover, Germany, 2014. 
28. Guinée, J.B.; Gorrée, M.; Heijungs, R.; Huppes, G.; Kleijn, R.; de Koning, A.; van Oers, L.; Sleeswijk, A.W.; Suh, S.; de Haes, H.A.U.; et al. Handbook on Life Cycle Assessment Operational Guide to the ISO Standards; Kluwer Academic Publishers: New York, NY, USA, 2002.

29. Lehmann, A.; Bach, V.; Finkbeiner, M. Product environmental footprint in policy and market decisions-Applicability and impact assessment. Integr. Environ. Assess. Manag. 2015. [CrossRef] [PubMed]

30. Finkbeiner, M.; Ackermann, R.; Bach, V.; Berger, M.; Brankatschk, G.; Chang, Y.-J.; Grinberg, M.; Lehmann, A.; Martínez-Blanco, J.; Minkov, N.; et al. Challenges in Life Cycle Assessment: An Overview of Current Gaps and Research Needs. In LCA Compendium-The Complete World of Life Cycle Assessment-Volume 1: Background and Future Prospects in Life Cycle Assessment; Klöpffer, W., Ed.; Springer: Dodrecht, The Netherlands, 2014; pp. 207-258.

31. Daimler, A.G. Life cycle-Environmental Certificate Mercedes-Benz C-Class including Plug-In Hybrid C 350 e. Stuttgart 2015, in press.

(C) 2016 by the authors; licensee MDPI, Basel, Switzerland. This article is an open access article distributed under the terms and conditions of the Creative Commons by Attribution (CC-BY) license (http://creativecommons.org/licenses/by/4.0/). 